\title{
Investigation of negative effects of rice husk silica on komatsuna growth using three experiments
}

\author{
Ryoko Sekifuji ${ }^{1} \cdot$ Le Van $^{C}$ Rieu $^{2} \cdot$ Masafumi Tateda $^{1} \mathbb{C}$
}

Received: 12 June 2019 / Accepted: 23 September 2019 / Published online: 3 October 2019

(c) The Author(s) 2019

\begin{abstract}
Purpose This study aims to evaluate the potential negative effects of rice husk as a source of fertilizer on plant growth. Methods Growth tests were conducted on komatsuna (Brassica rapa var. perviridis) using three types of experiment. A pot experiment was conducted to compare different fertilizers on an individual basis. A second pot experiment was conducted to compare different mixtures of fertilizers. Finally, a field experiment was performed to determine the effects of the application of different quantities of silica.

Results The results showed that komatsuna grew better with the application of silica mixed with fertilizer, and that there was an optimal quantity of silica to be used, when used on its own. It was found that, in all cases, the silica in the rice husk ash did not have any measurable negative effects on the growth of the komatsuna.

Conclusions We, therefore, conclude that rice husk silica can undoubtedly be used for plant cultivation.
\end{abstract}

Keywords Rice husks $\cdot$ Ash silica $\cdot$ Fertilizer $\cdot$ Negative effects $\cdot$ Komatsuna $\cdot$ Growth

\section{Introduction}

Rice husks are one of the most trusted forms of biomass because of their sustainable generation and abundance. Rice husks are valuable sustainable resources for two purposes: energy recovery and material recovery. Their energy content is approximately $12 \mathrm{MJ} \mathrm{kg}^{-1}$ and they are a good source of fuel for producing hot water and steam. Rice husks contain silica, which can be a useful fertilizer for rice plants. This means that an ideal complete recycling scheme can be pursued (Fig. 1). Rice straw, which is generated along with rice husks, does not cause any problems in Japan because it

Masafumi Tateda

tateda@pu-toyama.ac.jp

Ryoko Sekifuji

ryoko@pu-toyama.ac.jp

Le Van Chieu

lechieu@vnu.edu.vn

1 School of Environmental Engineering, Toyama Prefectural University, 5180 Korokawa, Kosugi, Toyama 939-0398, Japan

2 Project Management Department, Vietnam National University, 14C Building, 144 Xuan Thuy, Cau Giay District, Hanoi, Vietnam is plowed into the soil; although, several recent researches have studied the recycling of rice straw (Kaur et al. 2019; Kadian et al. 2019).

The silica in rice husk is very useful and many researchers have reported its varied applications. Beside its numerous industrial applications, silica is quite beneficial for plants. Multiple researchers have reported the benefits of silica in rice husks, leading to the healthy growth of plants. Raven (1982) reported a comprehensive study on the total energy of silicon transport and its function in plants. Foy (1992) concluded that silicon causes an increase in phosphorus (P) efficiency, leaf size and chlorophyll content, and alleviation of aluminum ( $\mathrm{Al})$, iron $(\mathrm{Fe})$, and manganese $(\mathrm{Mn})$ in plants. The effect of silicon on the physical strength of plants, such as in their cell walls, was discussed by Guerriero et al. (2016). Most recently, silicon's role in tropical forest soils (Schaller et al. 2018) and its influence on numerous plants, such as maize, lettuce, wheat, carrot, and pea have been reported (Greger et al. 2018). Silicon fertilizers show improvements in crops, such as improved tolerance of biotic and abiotic stresses, and higher yields (Vasanthi et al. 2014). Effects of silica on specific plants have been investigated. Henriet et al. (2006) investigated the effect of silica on banana plants, and Dorneles et al. (2018) investigated its effect on potato plants. Silicon was found to 
Fig. 1 Ideal agriculture loop based on rice husk recycling

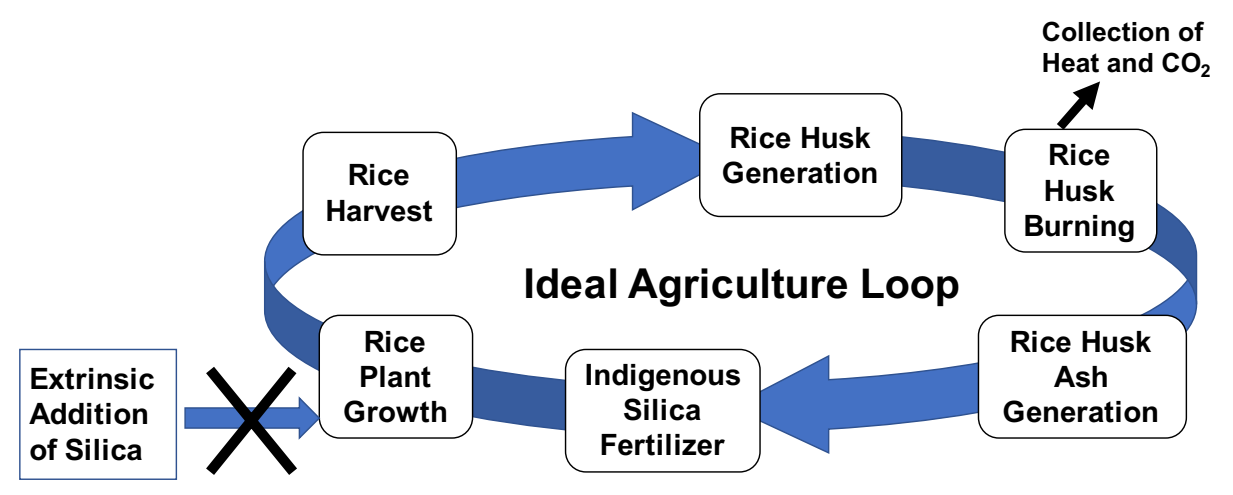

play an important role in these crops. Silicon has also been reported to have good effects on humans; it improves bone health and accelerates healing (Henstock et al. 2015) as well as improves the immune response and tissue health (Farroq and Dietz 2015). Since 1950s, there have been numerous researches on how silicon affects rice production (Yoshida et al. 1959, 1962; Krishnarao and Godkhindi 1992; Savant et al. 1996; Klotzbücher et al. 2015; Ito et al. 2015; Siregar et al. 2016; Waseem et al. 2016; Song et al. 2017).

The purpose of this study is to investigate the negative effects of silica in rice husk ash on the komatsuna plant using three different experiments. Komatsuna is a standard plant used in the evaluation of negative effects on plants in Japan. Kato et al. (2008) studied nitrate concentrations in komatsuna in an andisol. Furthermore, the flux of $\mathrm{N}_{2} \mathrm{O}$ from komatsuna influenced by slag fertilizers has been investigated (Singla and Inubushi 2015). The uptake of tellurium and cesium from the soil by komatsuna plants has also been reported (Fujiwara et al. 2017).

Sekifuji and Tateda (2017) investigated the negative effect of silica in rice husks on the taste of rice and found that no such effect was evident when using silica as a fertilizer. This was done to confirm that there is no negative effect of the rice husk silica on plants; thereby, promoting various applications of silica, especially recycling of rice husk silica. Moreover, rice husks could then be regarded not as waste but as a resource, which would help to promote a greener society in rice-producing countries.

\section{Materials and methods}

Rice husks of Koshihikari (Oryza sativa L.) were used for the following experiments. Rice husk ash was obtained by burning the husks in a field-scale boiler system (incineration capacity: $100 \mathrm{~kg}$ rice husks $\mathrm{h}^{-1}$ ) (Fig. 2).

The details of the boiler system are described by Tateda et al. (2016b). The silica in the ash was confirmed as amorphous using an X-ray diffraction analysis (XRD). The solubility of the silica was more than $50 \%$, thereby, indicating its amorphous state. The solubility percentage of silica is an official indicator, which is highly correlated with the amorphous state of silica. Higher the solubility percentage, the more amorphous the state will be. Details of the solubility measurements are described by Tateda et al. (2016a). Komatsuna (Brassica rapa var. perviridis), a Japanese

Fig. 2 Diagram of the boiler

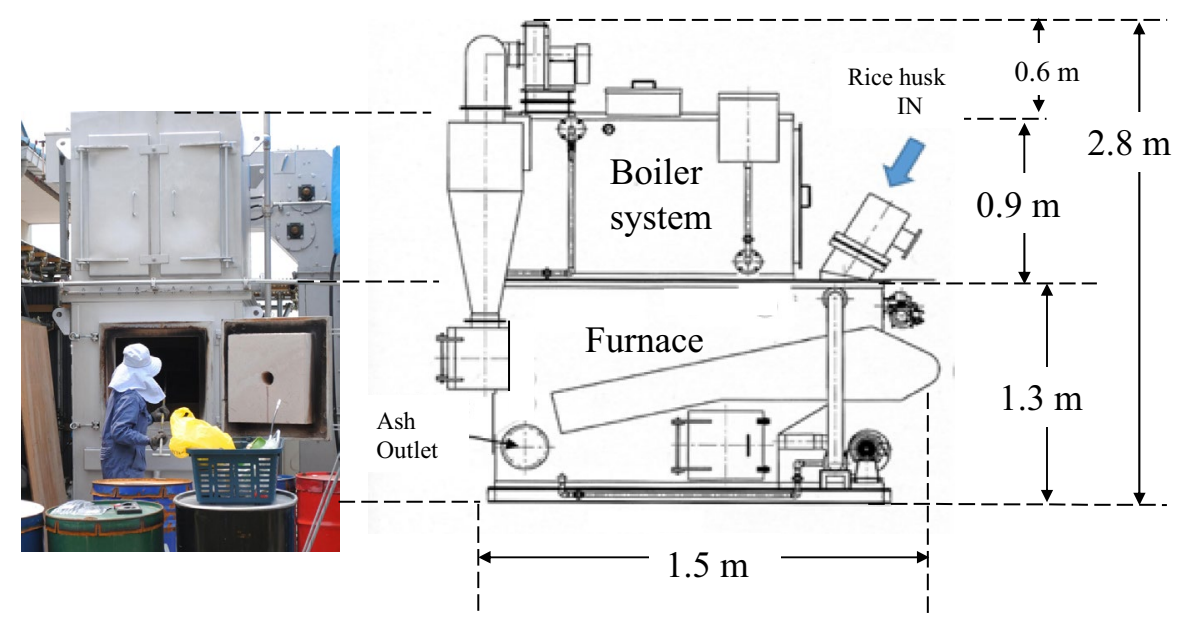

Front view

Side view 
mustard spinach, was used for all the experiments. Possible contamination by radioactive cesium in the rice husk ash was also analyzed, because all the experiments were conducted after a severe incident involving an explosion at a nuclear power plant that had been damaged by the strong earthquake, which hit the northern area of Japan on March 11th, 2011. Levels of radioactive cesium (Cs-134 and Cs-137) were measured using the standard method for measuring radioactive cesium in fertilizers (MAFF 2011).

\section{Pot experiment for comparison with different individual fertilizers}

The purpose of this experiment was to investigate the negative effects of rice husk ash as a fertilizer for komatsuna compared to other common fertilizers and compost, using cultivation pots. The experimental procedure followed the standard method for solubility tests of silica (MAFF 2007). Neubauer pots $\left(10^{-6}\right.$ ha; inner diameter $11.3 \mathrm{~cm} \times$ height $6.5 \mathrm{~cm}$ ) were used for the experiment. Diluvium was used as the base soil, and its characteristics are shown in Table 1. For comparison, a dried cell fertilizer and farm compost were used, and their characteristics are shown in Table 2. Because nitrogen content was less than $2 \%$ for SF and CF2, an application of $5 \mathrm{~g}$ (dry base) was set as the standard. For $\mathrm{CF} 1,100 \mathrm{mg}$ of nitrogen was set as the standard because the nitrogen content was more than $2 \%$ (dry base). The experimental design of the fertilizer and compost applications are shown in Table 3 . The cultivation was conducted in a glass room and the room temperature was kept above $15^{\circ} \mathrm{C}$, with

Table 1 Physical characteristics of the base soil (diluvium)

\begin{tabular}{ll}
\hline Type of soil & Values \\
\hline $\mathrm{pH}($ soil:water $=1: 2.5)$ & 6.3 \\
Exchangeable acidity & 0.3 \\
Electric conductivity $\left(\mathrm{mS} \mathrm{cm}^{-1}\right)$ & 0.15 \\
Cation exchange capacity $\left(\mathrm{mol}_{\mathrm{c}} \mathrm{kg}^{-1}\right)$ & 19.1 \\
Phosphate adsorption coefficient $\left(\mathrm{g} \mathrm{kg}^{-1}\right)$ & 28.6 \\
Air-dried fine soil volume weight $\left(\mathrm{g} \mathrm{500} \mathrm{ml}^{-1}\right)$ & 413 \\
Maximum water holding capacity $\left(\mathrm{g} \mathrm{kg}^{-1}\right)$ & 1100 \\
\hline
\end{tabular}

germination and growth observations conducted on days 5 and 9 , and on days 14 and 21 , respectively.

\section{Pot experiment for comparison with different mixtures of fertilizers}

The purpose of this experiment was to investigate the negative effects of rice husk ash mixed with compost on komatsuna using cultivation pots. The experimental procedure followed the standard method for solubility tests of silica (MAFF 2007). Neubauer pots $\left(10^{-6}\right.$ ha; inner diameter $11.3 \mathrm{~cm} \times$ height $6.5 \mathrm{~cm}$ ) were used for the experiment. Komatsuna was cultivated in a glass room at an average room temperature of $25^{\circ} \mathrm{C}$. Compost produced by mixing bark, poultry manure, tea dregs, pruned branches and/or leaves, and urea was used for making the bed materials for komatsuna growth. Tea dregs consisted of leaves left over from brewing tea, which is one of the most popular drinks in Japan. The experimental design is summarized in Table 4. Bed materials A, B, and C are compost products that are commercially available. Volcanic ash subsoil was used as the base soil. $150 \mathrm{ml}$ of the bed materials was added to the base soil $(350 \mathrm{ml})$, which was $71 \mathrm{~g}, 70 \mathrm{~g}, 45 \mathrm{~g}, 61 \mathrm{~g}, 50 \mathrm{~g}$, $49 \mathrm{~g}, 57 \mathrm{~g}, 51 \mathrm{~g}$, and $45 \mathrm{~g}$ for pots \#1, 2, 3, 5, 6, 7, 8, and 9 , respectively. $360 \mathrm{~g}$ of base soil was used for the control.

\section{Field experiment with different quantities of silica}

The purpose of this experiment was to investigate the negative effects of rice husk ash on komatsuna in field cultivation. Two greenhouses were used for the experiments. The configuration of the greenhouses and the experimental design are shown in Fig. 3.

Elemental components of the base soil in greenhouses A and $\mathrm{B}$, and the $\mathrm{pH}$ of each section are shown in Tables 5 and 6 . The $\mathrm{pH}$ of the soil in each section (Table 6) was measured by dissolving the soil in tap water $(\mathrm{pH} 7.31)$ at ratio of 2:1 (soil:water) by weight. Resistance values to lodging were also obtained to evaluate the negative effects of the rice husk ash on komatsuna (Fig. 4). Seeding was conducted at the end of November 2013 and harvesting was conducted at the beginning of February 2014.

Table 2 Characteristics of fertilizers used

\begin{tabular}{lllllrrr}
\hline Short name & Name & Materials & \multicolumn{4}{l}{ Fertilizer effective components (\%) } \\
\cline { 5 - 7 } & & & Water content & $\mathrm{N}$ & $\mathrm{P}_{2} \mathrm{O}_{5}$ & $\mathrm{~K}_{2} \mathrm{O}$ & $\mathrm{C} / \mathrm{N}$ \\
\hline $\mathrm{SF}$ & Sample fertilizer & Rice husk ash & 6.1 & $0.11(0.12)$ & $0.19(0.20)$ & $1.92(2.05)$ & 112 \\
$\mathrm{CF} 1$ & Comparison fertilizer 2 & Dried cell fertilizer & 7.1 & $5.08(5.47)$ & $2.27(2.44)$ & $0.19(0.20)$ & 6 \\
$\mathrm{CF} 2$ & Comparison fertilizer 1 & Farm compost & 45.4 & $1.00(1.82)$ & $1.32(2.42)$ & $1.53(2.81)$ & 17 \\
\hline
\end{tabular}

Values in parentheses indicate the percentage in dry base 
Table 3 Design of fertilizers

\begin{tabular}{clllll}
\hline Short name & Application design & $\begin{array}{l}\text { Application amount } \\
\left(\mathrm{g} \mathrm{pot}^{-1}\right)\end{array}$ & $\begin{array}{l}\text { Fertilizer effective components } \\
\left(\mathrm{mg} \mathrm{pot}^{-1}\right)\end{array}$ & & \\
\cline { 4 - 5 } & & & $\mathrm{N}$ & $\mathrm{P}_{2} \mathrm{O}_{3}$ & $\mathrm{~K}_{2} \mathrm{O}$ \\
\hline SF & & & & \\
SFS & Standard & 5.3 & $6(25)$ & $10(50)$ & $102(25)$ \\
SFD & Double & 10.7 & $12(25)$ & $20(50)$ & $205(25)$ \\
SFT & Triple & 16.0 & $18(25)$ & $30(50)$ & $307(25)$ \\
SFQ & Quadruple & 21.3 & $23(25)$ & $41(50)$ & $409(25)$ \\
CF1 & & & & \\
CF1S & Standard & 2.0 & $100(25)$ & $45(50)$ & $4(25)$ \\
CF1D & Double & 3.9 & $200(25)$ & $89(50)$ & $7(25)$ \\
CF1T & Triple & 5.9 & $300(25)$ & $134(50)$ & $11(25)$ \\
CF1Q & Quadruple & 7.9 & $400(25)$ & $179(50)$ & $15(25)$ \\
CF2 & & & & & $140(25)$ \\
CF2S & Standard & 9.2 & $92(25)$ & $121(50)$ & $140(25)$ \\
CF2D & Double & 18.3 & $183(25)$ & $242(50)$ & $280(25)$ \\
CF2T & Triple & 27.5 & $275(25)$ & $363(50)$ & $420(25)$ \\
CF2Q & Quadruple & 36.6 & $366(25)$ & $484(50)$ & $561(25)$ \\
& Control & & 25 & 50 & 25 \\
\hline
\end{tabular}

Values in parentheses indicate the amounts of ammonium sulfate, superphosphate, and potassium chloride used for $\mathrm{N}, \mathrm{P}_{2} \mathrm{O}_{3}$, and $\mathrm{K}_{2} \mathrm{O}$, respectively

Table 4 Experimental design and physical states

\begin{tabular}{|c|c|c|c|c|c|c|}
\hline \multirow[t]{2}{*}{ Pot \# name } & \multirow[t]{2}{*}{ Components of bed materials } & \multicolumn{2}{|c|}{ Mixing percentage by weight (\%) } & \multicolumn{3}{|l|}{ Physical states } \\
\hline & & Bed material & Rice husk ash & $\begin{array}{l}\text { Water content } \\
(\%)\end{array}$ & $\mathrm{pH}$ & $\begin{array}{l}\text { Electric conduc- } \\
\text { tivity }\left(\mathrm{mS} \mathrm{cm}^{-1}\right)\end{array}$ \\
\hline \multicolumn{7}{|l|}{1} \\
\hline A10 & $\mathrm{A}$ & 90 & 10 & 51.8 & 8.4 & 1.3 \\
\hline 2 & Bark $94.0 \%$ & & & & & \\
\hline $3^{\mathrm{A} 30}$ & $\begin{array}{l}\text { Poultry manure } 5.0 \% \\
\text { Urea } 1.0 \%\end{array}$ & 70 & 30 & 52.5 & 8.8 & 0.9 \\
\hline A 50 & & 50 & 50 & 35.6 & 9.0 & 2.0 \\
\hline \multicolumn{7}{|l|}{4} \\
\hline B10 & $\mathrm{B}$ & 90 & 10 & 53.4 & 7.8 & 1.4 \\
\hline 5 & Bark 52.3\% & & & & & \\
\hline B30 & $\begin{array}{l}\text { Tea dregs } 22.5 \% \\
\text { Pruned branches and leaves } 22.5 \%\end{array}$ & 70 & 30 & 53.8 & 8.6 & 1.6 \\
\hline 6 & Poultry manure $2.2 \%$ & & & & & \\
\hline B50 & Urea $0.5 \%$ & 50 & 50 & 46.9 & 9.0 & 1.7 \\
\hline \multicolumn{7}{|l|}{7} \\
\hline $\mathrm{C} 10$ & $\mathrm{C}$ & 90 & 10 & 53.4 & 6.2 & 1.7 \\
\hline${ }^{8} \mathrm{C} 30$ & $\begin{array}{l}\text { Tea dregs } 50.0 \% \\
\text { Pruned branches and leaves } 50.0 \%\end{array}$ & 70 & 30 & 51.2 & 6.6 & 1.7 \\
\hline \multicolumn{7}{|l|}{9} \\
\hline $\mathrm{C} 50$ & & 50 & 50 & 45.4 & 7.6 & 2.0 \\
\hline & Control & - & - & $149.5^{\mathrm{a}}$ & $6.4^{\mathrm{b}}$ & $0.13^{\mathrm{c}}$ \\
\hline
\end{tabular}

Values of a, b, and c are from Saito et al. (1987)

${ }^{a}$ Maximum water holding capacity

${ }^{\mathrm{b}} \mathrm{pH}$

${ }^{\mathrm{c}}$ Electric conductivity of volcanic ash subsoil 
Fig. 3 Configuration of the experimental sections in the fields
Greenhouse A:

Field with no rice husk ash applied.

Greenhouse B:

Field with rice husk ash applied.
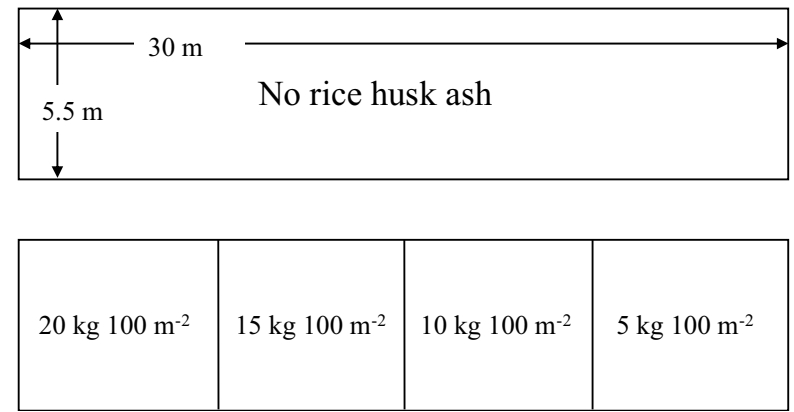

Table 5 Soil analysis (\%)

\begin{tabular}{lll}
\hline Elements & Soil in greenhouse A & $\begin{array}{l}\text { Soil in } \\
\text { green- } \\
\text { house B }\end{array}$ \\
\hline $\mathrm{Fe}$ & 43.2 & 43.1 \\
$\mathrm{Si}$ & 33.8 & 33.5 \\
$\mathrm{Ca}$ & 8.1 & 9.1 \\
$\mathrm{~K}$ & 7.5 & 6.5 \\
$\mathrm{Ti}$ & 2.8 & 3.1 \\
$\mathrm{Ba}$ & 2.1 & 0.7 \\
$\mathrm{Mn}$ & 0.6 & 0.9 \\
$\mathrm{Zn}$ & 0.4 & 0.4 \\
$\mathrm{Sr}$ & 0.4 & 0.3 \\
$\mathrm{Zr}$ & 0.4 & - \\
$\mathrm{Cr}$ & 0.2 & 0.2 \\
$\mathrm{Rb}$ & 0.2 & 0.2 \\
$\mathrm{Ag}$ & 0.2 & - \\
$\mathrm{Y}$ & 0.1 & - \\
$\mathrm{S}$ & - & 1.9
\end{tabular}

Table $6 \mathrm{pH}$ of the soil in each section

\begin{tabular}{ll}
\hline Soil & $\mathrm{pH}$ \\
\hline Soil in greenhouse A & 5.17 \\
Soil in greenhouse B & 5.38 \\
Soil in the section of $5 \mathrm{~kg} 100 \mathrm{~m}^{-2}$ & 5.12 \\
Soil in the section of $10 \mathrm{~kg} 100 \mathrm{~m}^{-2}$ & 5.40 \\
Soil in the section of $15{\mathrm{~kg} 100 \mathrm{~m}^{-2}}^{-2}$ & 5.28 \\
Soil in the section of $20{\mathrm{~kg} 100 \mathrm{~m}^{-2}}$ & 5.48 \\
\hline
\end{tabular}

\section{Results and discussion}

\section{Pot experiment for comparison with mixed single fertilizer (experiment 1)}

Germination occurred in all the application designs, and showed equal or much better results, as compared to the control (data not shown). Abnormalities were not seen in

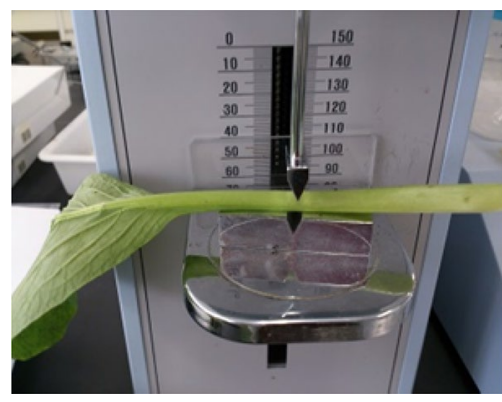

Fig. 4 Resistance values test (leaf stem)

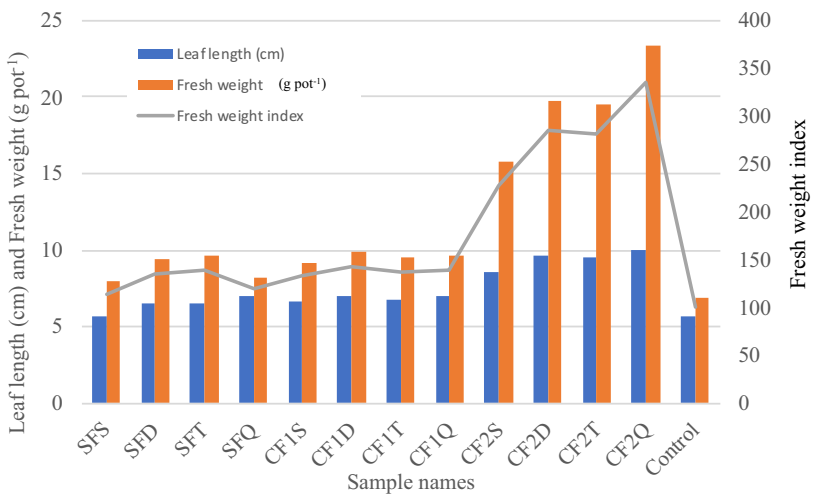

Fig. 5 Leaf length, fresh weight, and fresh weight index observed on the 21 st day

any of the application designs. Growth observations on the 21st day are graphed in Fig. 5. The fresh weight index shows the proportion of fresh weight for each sample, taking the value of control (6.9 g) as 100 . For both leaf length and fresh weight, all the application designs showed larger values than the control. In the case of leaf length, SF and CF2 showed an increase with increasing application of ash, though the values were almost the same for CF1. For fresh weight, CF2 showed an increase with increasing application of ash, and the increase was significant. In the case of SF, the standard and quadruple applications showed minimum values. A similar trend was seen in CF1. The status of growth of komatsuna is shown in 
Fig. 6 Growth observation; left: germination on the 9th day; right: growth on the 21 st day
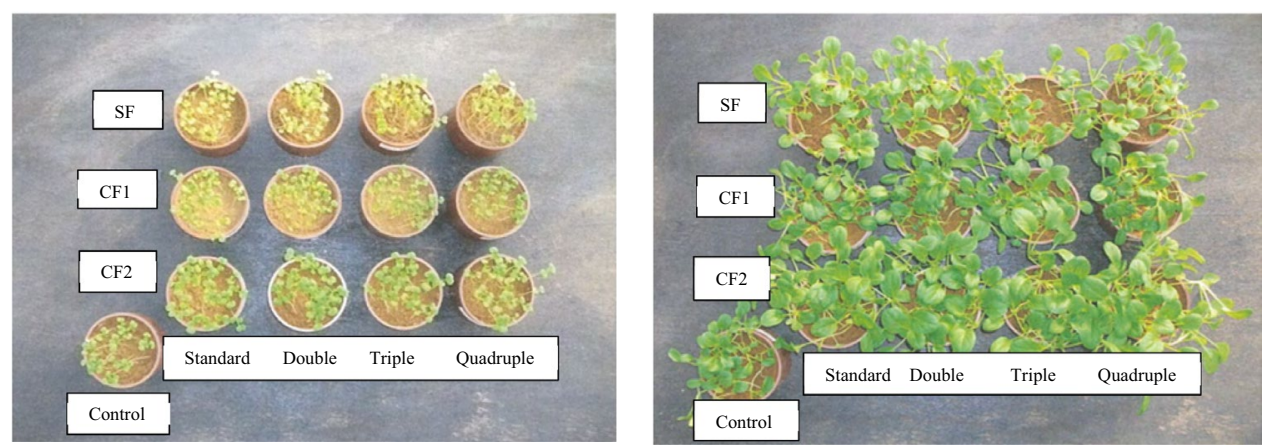

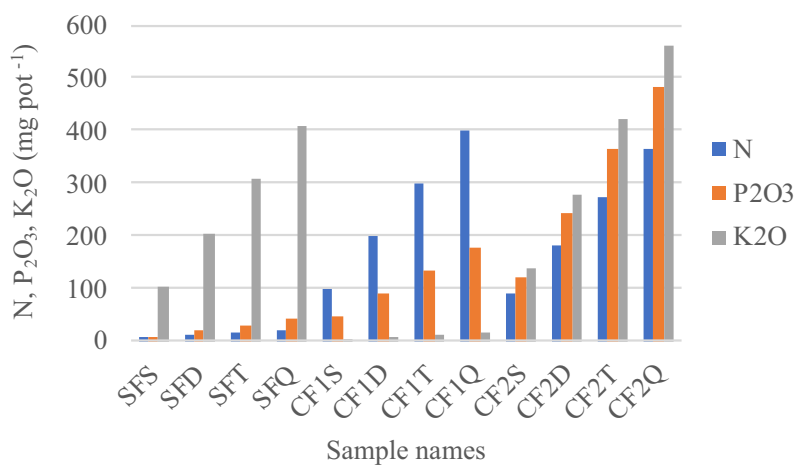

Fig. 7 Nutrient contents for each sample

Fig. 6; CF2 had grown significantly compared to SF and CF1 by the 21st day. Figure 7 shows that the sample CF2 had significant growth in terms of fresh weight, because its $\mathrm{N}, \mathrm{P}_{2} \mathrm{O}_{3}$, and $\mathrm{K}_{2} \mathrm{O}$ were very high compared with the other samples. SF and CF1 contained small amounts of N, $\mathrm{P}_{2} \mathrm{O}_{3}$, and $\mathrm{K}_{2} \mathrm{O}$, which might be a reason that they did not grow as much as $\mathrm{CF} 2 \mathrm{did}$.

\section{Pot experiment for comparison with mixed multiple fertilizers (experiment 2)}

The growth tests for abnormality revealed no abnormality in any of the pots (results not shown). In all the pots, normal growth of komatsuna was confirmed throughout the experiments, and $100 \%$ germination was observed for all applications, which was better than the control (Fig. 10). Leaf length, fresh weight, and fresh weight index are graphed in Fig. 8, and the chlorophyll content in the leaves was measured as SPAD (Fig. 9). The fresh weight index shows the proportional fresh weight for each sample, taking the value of control (2.8 g) as 100 . Bed material A had a greater influence than bed materials B and C; however, all three produced far better growth than the control (Fig. 8). In bed material A, sample A30 had the highest fresh weight, and A50 decreased substantially to become

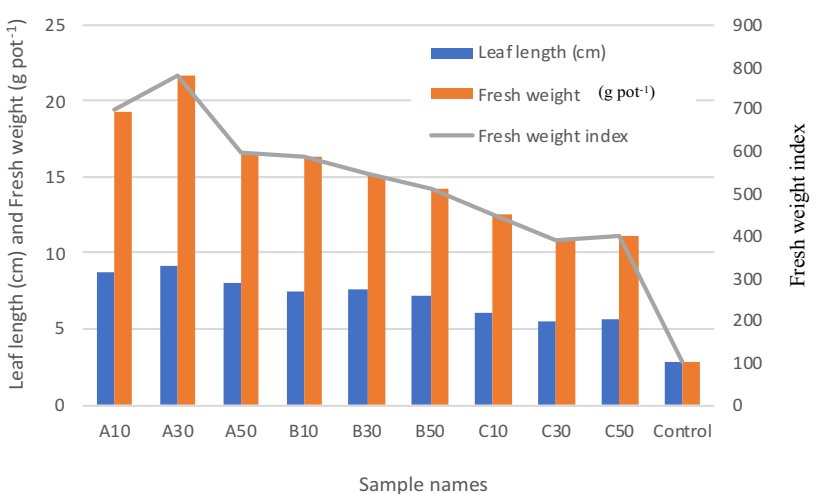

Fig. 8 Leaf length, fresh weight, and fresh weight

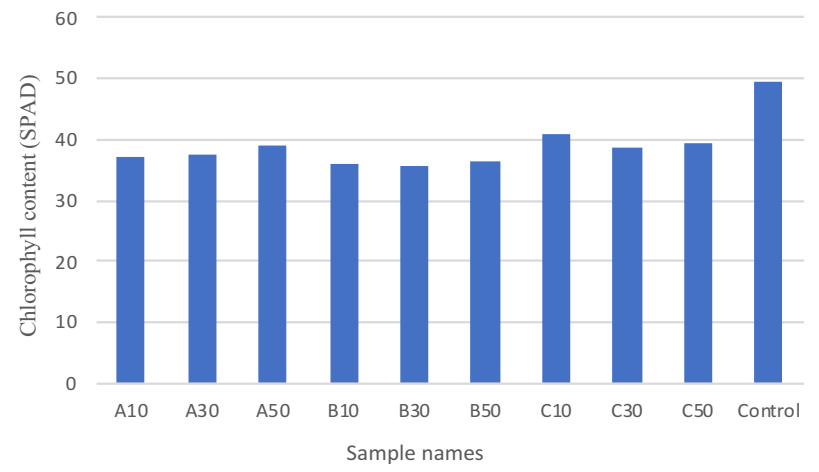

Fig. 9 Chlorophyll content of the leaves index observed on the 21st day

the smallest in group A. Group A showed the highest fresh weight, followed by group B; the least fresh weight was seen in group C. In groups B and C, no significant difference was observed among the samples. It can be said that fresh weight was influenced by the types of fertilizer. Figure 10 shows the status of growth for all pots; the control grew less than the other pots. The SPAD values of control were the highest (Fig. 9), which may be attributed to the fact that its leaves remained small; hence, the chlorophyll content showed a higher value. 
Fig. 10 Growth observation of each pot after the 9 th and 21 st day

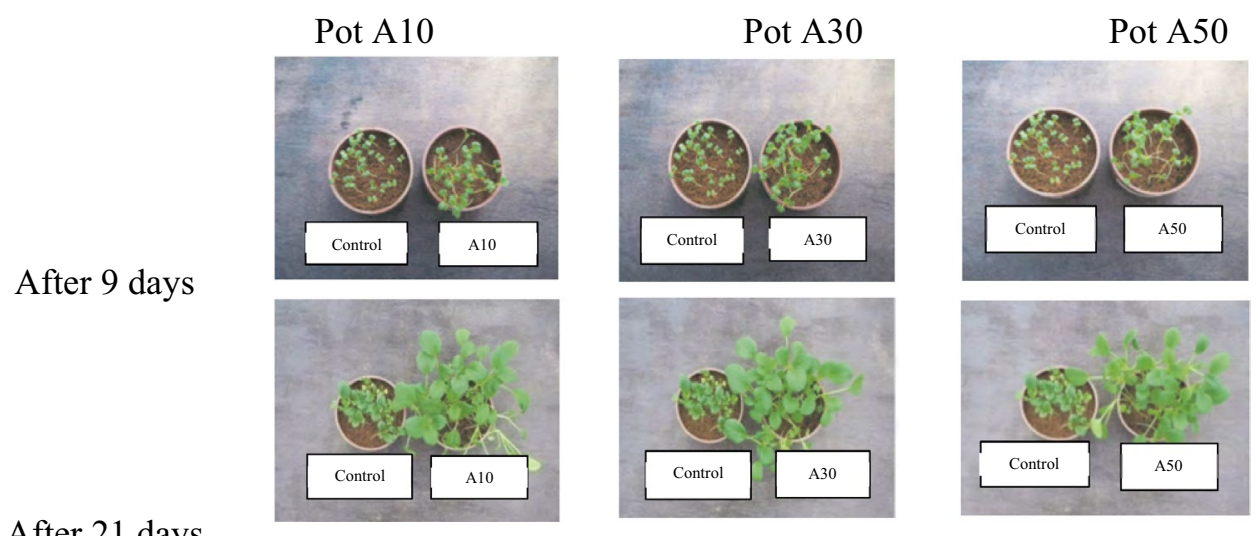

After 21 days

Pot B10

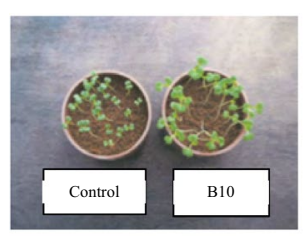

After 9 days

After 21 days

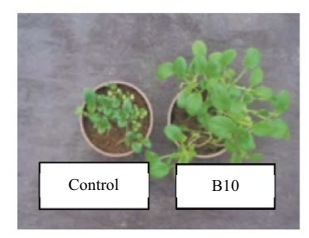

Pot C10

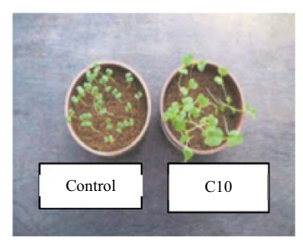

After 9 days

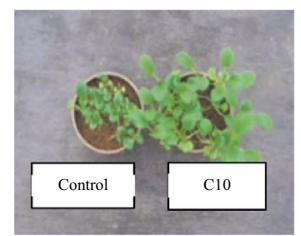

Pot B30
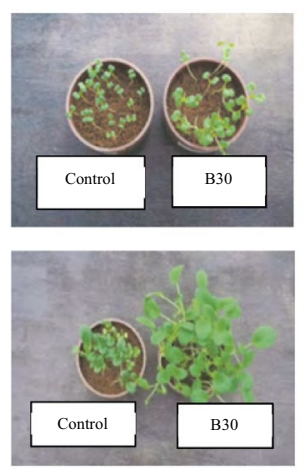

Pot C30
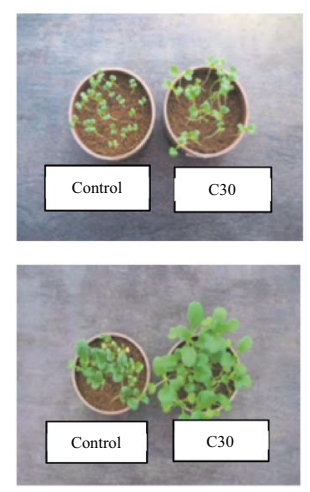

Pot B50
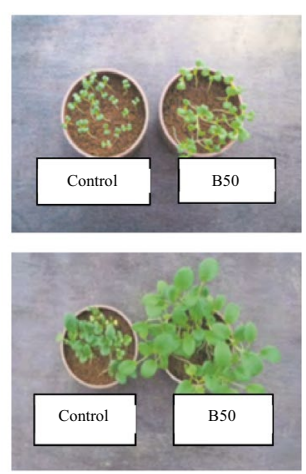

Pot C50
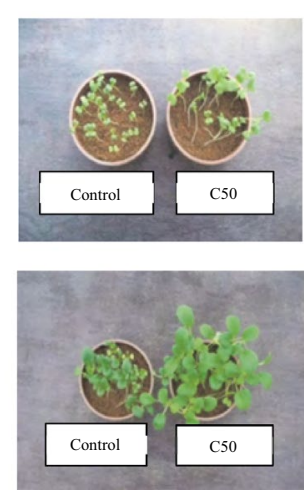

After 21 days

\section{Field experiment with different quantities of silica (experiment 3)}

Figure 11 shows that there were no significant negative effects caused by the use of rice husk ash, compared with the control sample. There were also no significant positive effects from the application of ash, compared to the control sample. The addition of $20 \mathrm{~kg} 100 \mathrm{~m}^{-2}$ of ash might reduce the total sellable weight of komatsuna. In Fig. 5, SF is the sample with only rice husk ash addition; comparing the fresh weight of SF in Fig. 5 with the total weight in Fig. 11, the same trend of the samples with $1 \times, 2 \times, 3 \times$, and $4 \times$ ash can be seen. The values increased with increasing ash amount, but decreased in the sample with $4 \times$ the ash, although the controls for each showed different trends. In the field experiment, control showed a better performance in all parameters compared to the other samples (Fig. 11); but in the pot experiments, control showed the least amount of growth, 


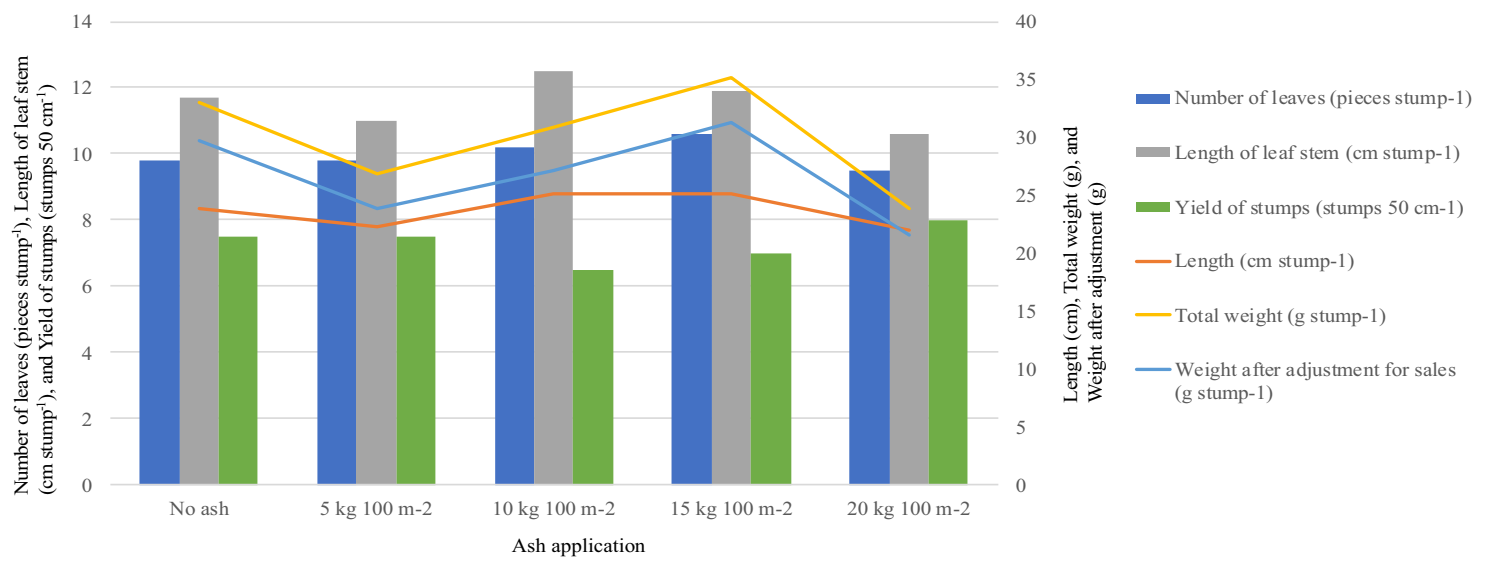

Fig. 11 Results of growth tests in the field

Fig. 12 Resistance values of leaves and leaf stems

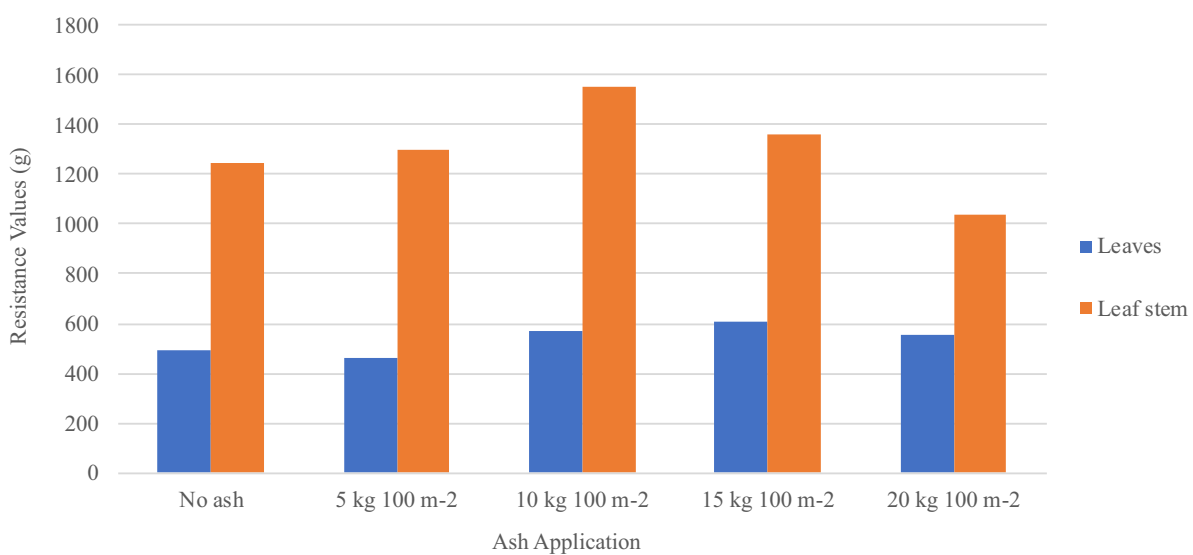

compared to all the samples (Fig. 5). The resistance values of the leaves were not significant for all samples; however, for the leaf stems, the sample with 10-kg ash application showed the highest value (Fig. 12). The results imply that the addition of ash to the soil did not cause weakening of the leaves or leaf stems of komatsuna.

\section{Conclusions}

To evaluate negative effects of rice husk ash application on komatsuna crops, three experiments were conducted. The following conclusions were obtained.

1. Komatsuna grew significantly when the ash was used in combination with a fertilizer.

2. Application of the ash without fertilizer did not result in significant improvement in the growth of komatsuna.

3. Rice husk ash did not have a negative effect on the komatsuna, whether applied with or without fertilizer, in pot or field experiments.
Because of a previous experiment, which showed that rice husk ash did not impair the taste of rice (Sekifuji and Tateda 2017), it was concluded that it can be used safely for komatsuna. Thus, rice husk ash can be used for any kind of vegetables, without having negative effects on the plants. With fertilizers, ash had significantly positive effects on komatsuna, and the plants became healthier.

Acknowledgements The authors deeply thank the people who supported the experiments.

\section{Compliance with ethical standards}

Conflict of interest The authors declare that they have no conflict of interest.

Open Access This article is distributed under the terms of the Creative Commons Attribution 4.0 International License (http://creativeco mmons.org/licenses/by/4.0/), which permits unrestricted use, distribution, and reproduction in any medium, provided you give appropriate credit to the original author(s) and the source, provide a link to the Creative Commons license, and indicate if changes were made. 


\section{References}

Dorneles AOS, Pereira AS, Possebom G, Sasso VM, Rossato LV, Tabaldi LA (2018) Growth of potato genotypes under different silicon concentrations. Adv Hortic Sci 32(2):289-295

Farroq MA, Dietz K-J (2015) Silicon as versatile player in plant and human biology: overlooked and poorly understood. Front Plant Sci 12:1-14

Foy CD (1992) Soil chemical factors limiting plant root growth. Adv Soil Sci 19:97-149

Fujiwara K, Takahashi T, Kinouchi T, Fukutani S, Takahashi S, Watanabe T, Funakuawa S (2017) Transfer factors of Tellurium and Cesium from soil to radish (Raphanus sativus var. sativus) and Komatsuna (Brassica rapa ver. perviridis). Jpn J Health Phys 52(3):192-199

Greger M, Landberg T, Vaculík M (2018) Silicon influence soil availability and accumulation of mineral nutrient in various plant species. Plant 7(2):41. https://doi.org/10.3390/plants7020041

Guerriero G, Hausman J-F, Legay S (2016) Silicon and the plant extracellular matrix. Front Plant Sci 7:1-8

Henriet C, Draye X, Oppitz I, Swennen R, Delvaux B (2006) Effects, distribution and uptake of silicon in banana (Musa spp.) under controlled conditions. Plant Soil 287:359-374

Henstock JR, Canham LT, Anderson SI (2015) Silicon: the evolution of its use in biomaterials. Acta Biomater 11:17-26

Ito K, Endoh K, Shiratori Y, Inubushi K (2015) Silicon elution from three types of steel fertilizers in a paddy field analyzed by electron probe micro-analyzer (EPMA). Soil Sci Plant Nutr 61:835-845

Kadian N, Yadav K, Jangra E, Aggarwal A (2019) Influence of host plant and rice straw as substrate on mass multiplication of arbuscular mycorrhizal fungi for large-scale agricultural application. Int J Recycl Org Waste Agric. https://doi.org/10.1007/s4009 3-019-0255-9

Kato K, Ueta T, Matsumoto E (2008) Control of nitrate concentration in komatsuna (Brassica rapa L. Perviridis Group) plants in a greenhouse at high temperature seasons in the andisols area. Hortic Res Jpn 7(3):345-350

Kaur P, Kocher GS, Taggar MS (2019) Enhanced bio-composting of rice straw using agricultural residues: an alternate to burning. Int J Recycl Org Waste Agric. https://doi.org/10.1007/s4009 3-019-0263-9

Klotzbücher T, Marxen A, Vetterlein D, Schneiker J, Türke M, Sinh NV, Manh NH, Chien HV, Marquez L, Villareal S, Bustamante JV, Jahn R (2015) Plant-available silicon in paddy soils as a key factor for sustainable rice production in Southeast Asia. Basic Appl Ecol 16(8):665-673

Krishnarao RV, Godkhindi MM (1992) Distribution of silica in rice husks and its effect on the formation of silicon carbide. Cera Int 18(4):243-249

MAFF (Ministry of Agriculture, Forestry and Fisheries) (2007) Standard method of plant cultivation for evaluating negative effects against plants. http://www.maff.go.jp/j/kokuji_tuti/tuti/pdf/t0000 056_p001.pdf. Accessed 5 Sept 2019

MAFF (Ministry of Agriculture, Forestry and Fisheries) (2011) Standard method for measuring radioactive cesium in fertilizers. http:// www.maff.go.jp/j/syouan/nouan/hiryou/pdf/betten.pdf. Accessed 5 Sept 2019

Raven JA (1982) The transport and function of silicon in plants. Biol Rev 58:179-207

Saito T, Watanabe K, Takahashi M (1987) Kazanbai-dojo-kasoudo no tokotuchi riyou to rinsan-hiryo no seyo-ryo ga onshitsu meron no hinshitsu ni oyobosu eikyo (Influence on the quality of melons by the use as bed soil of volcanic ash subsoil and the application dosage of the phosphate fertilizers). Jpn Soc Soil Sci Plant Nutr 58(1):12-20

Savant NK, Snyder GH, Datnoff LE (1996) Silicon management and sustainable rice production. Adv Agron 58:151-199

Schaller J, Turner BL, Weissflog A, Pino D, Bielnicka AW, Engelbrecht BMJ (2018) Silicon in tropical forests: large variation across soils and leaves suggests ecological significance. Biogeochemistry 140:161-174

Sekifuji R, Tateda M (2017) Taste evaluation of rice grown in soil treated with commercial silica and recycled rice husk silica. J Sci Res Rep 17(3):1-9

Singla A, Inubushi K (2015) Effect of slag-type fertilizers on $\mathrm{N}_{2} \mathrm{O}$ flux from komatsuna vegetated soil and $\mathrm{CH}_{4}$ flux from paddy vegetated soil. Paddy Water Environ 13:43-50

Siregar AF, Sipahutar IA, Husnain Wibowo H, Sato K, Wakatsuki T, Masunaga T (2016) Influence of water management and silica application on rice growth and productivity in central Java. Indones J Agric Sci 8(12):86-99

Song A, Fan F, Yin C, Wen S, Zhang Y, Fan X, Liang Y (2017) The effects of silicon fertilizer on denitrification potential and associated genes abundance in paddy soil. Biol Fertil Soils 53(6):627-638

Tateda M, Sekifuji R, Yasui M, Yamazaki A (2016a) A proposal for measuring solubility of the silica in rice husk ash. J Sci Res Rep 11(3): $1-11$

Tateda M, Sekifuji R, Yasui M, Yamazaki A (2016b) Case study: technical consideration to optimize rice husk burning in a boiler to retain a high solubility of the silica in rice husk ash. J Sci Res Rep 11(4):1-11

Vasanthi N, Saleena LM, Raj SA (2014) Silicon in crop production and crop protection-a review. Agric Rev 35(1):14-23

Waseem M, Ahmad R, Randhawa MA, Aziz T, Mahmood N (2016) Influence of silicon application on blast incidence and lodging resistance in rice. J Agric Res 54(3):435-443

Yoshida S, Ohnishi Y, Kitaguchi K (1959) The chemical nature of silicon in rice plant. Soil Sci Plant Nutr 5(1):23-27

Yoshida S, Ohnishi Y, Kitaguchi K (1962) Chemical forms, mobility and deposition of silicon in rice plant. Soil Sci Plant Nutr $8(3): 15-21$

Publisher's Note Springer Nature remains neutral with regard to jurisdictional claims in published maps and institutional affiliations. 